\title{
History and Present Status of Ostrich Farming in Botswana
}

\author{
John Cassius Moreki $^{{ }^{*}}$, Mogi Ivy Moseki ${ }^{2}$, and Freddy Manyeula ${ }^{1}$ \\ ${ }^{\prime}$ Department of Animal Sciences, Faculty of Animal and Veterinary Sciences, Botswana University of Agriculture and Natural Resources, \\ Private Bag 0027, Gaborone, Botswana \\ ${ }^{2}$ Department of Agricultural Research Statistics and Policy Development, Ministry of Agricultural Development and Food Security, \\ Private Bag 003, Gaborone, Botswana \\ *Corresponding author’s email: jmoreki@buan.ac.bw; ORCID: 0000-0003-2932-3359
}

Received: 05 October 2021

Accepted: 18 November 2021

\begin{abstract}
Botswana boasts the world's largest population of wild ostriches estimated at approximately 60000 while farmed ostriches are less than 400. In this review, the history of the ostrich industry in Botswana is described and the current status is highlighted. Commercial ostrich farming in Botswana started in the early 1980s with the capture of birds from the wild, purchase of birds from local farmers, and importation of adult birds from neighboring countries, such as Namibia, South Africa, and Zimbabwe. However, the industry has not performed well over time as shown by a sharp decline in farmed ostrich populations which deleteriously affected throughput. To date, there is no commercial ostrich farming in Botswana indicating the collapse of the industry. This is despite the existence of favorable climatic conditions and government support in the form of provision of technical support through Ministry of Agriculture extension services, provision of loans at highly subsidized interest rates through Citizen Entrepreneurial Development Agency (CEDA), the existence of the EU accredited export abattoir and establishment of Dibete Ostrich Multiplication Unit (DOMU). The major challenges affecting the ostrich industry are frequent closures of the abattoir, lack of access to finance/credit, inadequacy of extension service, high feed expense, and unreliable feed supply. For the industry to be revived, it is recommended that government develops a special support program that subsidizes feed and ostrich stock, as well as, encouraging the formation of producer cooperative societies. In addition, participation of the private sector is paramount in the resuscitation of the ostrich industry.
\end{abstract}

Keywords: Botswana Ostrich Company, challenges, EU, DOMU, Ostrich farming, Ostrich meat

\section{INTRODUCTION}

Ostrich farming started during 1857-1860 in South Africa by catching wild birds and keeping them in camps and paddocks (Beyleveld, 1967). According to Shanawany (1995), ostrich farming started in South Africa with the establishment of the first commercial ostrich farm in 1860 to harvest feathers every 6 to 8 months. Thereafter, it spread to other parts of the world, such as Argentina, Australia, Egypt, New Zealand, and the United States of America until farmed ostriches reached one million by 1913. Prior to this, ostriches were hunted for their highly prized feathers which were a very fashionable trimming for ladies' hats and clothing in Europe (Wessels, 2003). This makes the domestication of ostriches much more recent than other livestock species that have been farmed for a long time (Snyders, 2020). To date, ostrich farming is practiced across the globe, indicating that ostriches can be reared in a wide range of climatic conditions although they do well in semi-arid to arid climatic conditions. South
Africa remains the global leader in ostrich production with $75 \%$ of the global market share (DAFF, 2011).

Ostrich farms are considered one of the most profitable agricultural projects. As a result, they are referred to as the farms of the future due to a wide variety of possible products and hence their high-profit potential. The three main products in ostrich production include meat, leather/skins, and feathers (Shanawany, 1995) but the main sources of income are meat and leather for the ostrich farmer, representing approximately $90 \%$ of the total income from a slaughtered bird (Cloete, 2014). Feathers constitute the remainder of the income. Ostrich meat is high in protein and iron and low in cholesterol, fat, and energy, and it is an alternative to red meat, especially for patients (Abdelkader, 2018). In addition, ostrich meat has low sodium content, a heart-healthy lipid profile, high content of vitamin B12, and superior levels of zinc and vitamin E (Medina and Aguilar, 2014). Therefore, ostrich meat is promoted as low-cholesterol red meat because of 
its red color, beef-like texture, and low-fat content (Jeffrey, 1993; Al-Khalifa and Al-Neser, 2014), and is preferred by the health-conscious market mainly in the western world (Chemis, 2009). Furthermore, ostrich meat is characterized by high polyunsaturated fatty acid contents, low saturated fatty acid content compared with red meats such as beef (Al-Khalifa and Al-Neser, 2014). Ostrich leather is thick, durable, extremely soft, and can be manufactured into various products, including shoes, bags, purses, and jackets (Shanawany, 1995). It is considered one of the finest and most expensive skins in the market (Abdelkader, 2018). In addition, Magige and Røskraft (2017) in Tanzania reported that ostriches were used for medical purposes with eggs and oil being used for the treatment of ailments, including asthma. The study by Eltom and Al-sehemi (2004) reported that ostrich oil obtained from the leg bones has been used as traditional medicine for the treatment of rheumatoid pain, burns, contact dermatitis, eczema, psoriasis, dry skin, dry hair conditions, bedsores, and other ailments. A recent study by Sadeghnejad et al. (2021) found ostrich oil to be effective in reducing pruritus in hemodialysis patients.

There is a lack of information and little expertise in ostrich farming in Botswana (BCA, 2008) perhaps indicating that it never received adequate research support. The industry has not performed well despite government support and good climatic conditions. Therefore, this review endeavors to describe the history of the ostrich industry in Botswana and to highlight its current status.

\section{HISTORY OF THE BOTSWANA OSTRICH INDUSTRY}

Although commercial ostrich farming in Botswana started in the early 1980s, it is still in its infancy to date (Moreki and Kgakole, 2015). This makes it one of the latest entrants of animal agriculture in Botswana. Birds were reared mainly for commercial purposes and this was driven by premium prices in the export market. Msheila et al. (2011) reported that the purposes of rearing ostriches in Northern Nigeria were commercial (85.7\%), leisure $(14.1 \%)$, and prior experience in poultry (14.1\%). A previous study by Barnes (1998) stated that ostrich farming is an attractive proposition for investors in Botswana and that it has the potential to contribute significantly to economic growth. The largest population of wild ostriches is found in Botswana, which is estimated to be 55916 to 60000 (Moreki and Kgakole, 2015; Malope et al., 2015) while domesticated ostriches were 380 (Statistics Botswana, 2018). Moreki and Kgakole (2015) posited that the largest number of wild ostriches found in Botswana could be indicative of an ideal environment for ostrich production as ostriches prefer a dry environment. On the other hand, BIDPA and The World Bank (2015) argued that the fact that Botswana has the world's largest population of wild ostriches does not imply that it is suitable for effective farming.

Ostrich farming began in earnest in Botswana with permits being granted to several entrepreneurs to breed and rear ostriches (Botswana Government, 1994; Barnes, 1998). Prior to this and during the early stages of the development of the ostrich industry, live exports of ostriches were allowed. Other countries that exported live ostriches were Namibia, South Africa, and Zimbabwe. While exports of live birds have been criticized for creating competition with the importing countries as the export prices were higher than that offered by the local market, Barnes (1998) reported that exports were economically beneficial for exporting countries. The author posited that for exports of live ostriches to be economically efficient in 1990, the price of exports had to be 9 to 21 times higher than the domestic price. Domestic price differentials that existed since 1990 were higher than 15:1 and mostly higher than 21:1 making a policy that allowed exports to be economically sound. Like South Africa, the ostrich industry in Botswana was exportoriented with very few products marketed locally. According to Anon (2008), ostrich meat was exported to Belgium and skins to Asia and South Africa. Gaoswediwe (2017) expressed that the local market is too small, thus making it expensive to market the meat locally.

Ostrich farming in Botswana started with the capture of birds from the wild, purchase of birds from local farmers, and importation of adult birds from neighboring countries, such as Namibia, South Africa, and Zimbabwe with a well-developed commercial ostrich industry. The Government came up with the Ostrich Management Plan Policy which allowed farmers to collect eggs from the wild to incubate and also collect chicks from the wild to raise as breeding stock on farms (Botswana Government, 1994). This was followed by the construction of the stateof-the-art ostrich abattoir in Gaborone in 2002, which according to The ComMark Trust/BIDPA (2005) and BIDPA and The World Bank (2006) was not approved to export meat to the European Union (EU) until August 2004. According to National Agricultural Marketing Council (2010), for ostrich meat to be exported to EU, abattoirs, and de-boning and packaging plants must be approved by the EU. The abattoir was built by Botswana Development Corporation (BDC) at a cost of P14 million 
and thereafter handed over to the government. The abattoir has the capacity to slaughter 30000 birds per year (Seleka, 2005). On the contrary, The ComMark Trust/ BIDPA (2005) and Moreki and Seabo (2011) reported that the abattoir's capacity was 20000 slaughter birds per annum. Seleka (2005) reported that the abattoir requires a minimum of 15000 slaughter birds per year to operate profitably and this was never achieved at any one time. Because of few ostriches reared across the country, the abattoir operated below capacity throughout its existence resulting in small amounts of ostrich meat exported.

Although Mushi et al. (1999) opined that the construction of the ostrich abattoir with the securing of the export market would persuade more farmers to produce ostriches, this did not seem to be the case as the abattoir was underutilized throughout its existence making it an unprofitable venture. The sole ostrich abattoir was first managed by the Botswana Ostrich Company (BOC), which ran the abattoir at a loss most of the time due to low supply volumes until it was later replaced by Multispecies Abattoir Botswana (MSAB), the current operator. The BOC exported only three tonnes of meat per month to some wholesale in Belgium. According to BIDPA and The World Bank (2006), the success of the ostrich industry depended upon the viability of $\mathrm{BOC}$ as the sole marketing channel for ostrich products in Botswana. Presently, no ostriches are slaughtered for export and/or local market as the industry has collapsed. However, intensive ostrich production has been described by Barnes (1998) to be a very attractive proposition for investors and has the potential to contribute significantly to economic growth in Botswana.

According to BIDPA and The World Bank (2006), the government of Botswana also supported the local ostrich industry by providing technical support through its extension services and its willingness to extend BDC loan facilities despite failure to repay the initial loan on schedule. In 1994, the government developed the Ostrich Management Plan Policy whose major objective is to promote sustainable commercial utilization of ostriches for the benefit of Botswana and its people. Furthermore, the government through Citizen Entrepreneurial Development Agency (CEDA) provides loans to farmers at highly subsidized interest rates. Additionally, in 2007 the government established Dibete Ostrich Multiplication Unit (DOMU) on 572-hectare land situated about $100 \mathrm{~km}$ northeast of Gaborone (the capital city of Botswana).

Dibete Ostrich Multiplication Unit had three objectives and these include assisting in the revival of the ostrich industry by acting as a catalyst; providing research, training, practical demonstration, and extension services by establishing satellite farms around Dibete village that will be directly supervised by DOMU; and providing breeding stock and chicks, as well as, hatching services (Moreki et al., 2012). It is apparent that DOMU only managed to fulfill the objective of providing breeding stock and chicks. As DOMU has not been able to achieve its objectives, the government plans to lease out the farm including the hatchery to the private sector (Hansard No. 200, 2020).

\section{CURRENT STATUS OF THE INDUSTRY}

Figure 1 illustrates farmed ostrich populations in Botswana from 2000 to 2020 . The trends show that the ostrich population generally declined over time. However, the ostrich population increased from 2000 to 2003 and thereafter declined up to 2006. The second rise in population is observed from 2006 to 2010 , which is followed by another decline. The population of commercial ostriches decreased from 6000 in 2006 to 409 in 2020. At present, there is not a single commercial ostrich farm that is operational in Botswana. Only one ostrich farm belonging to the government is operational and it is estimated to have less than 500 ostriches of different ages (DAP, 2021).

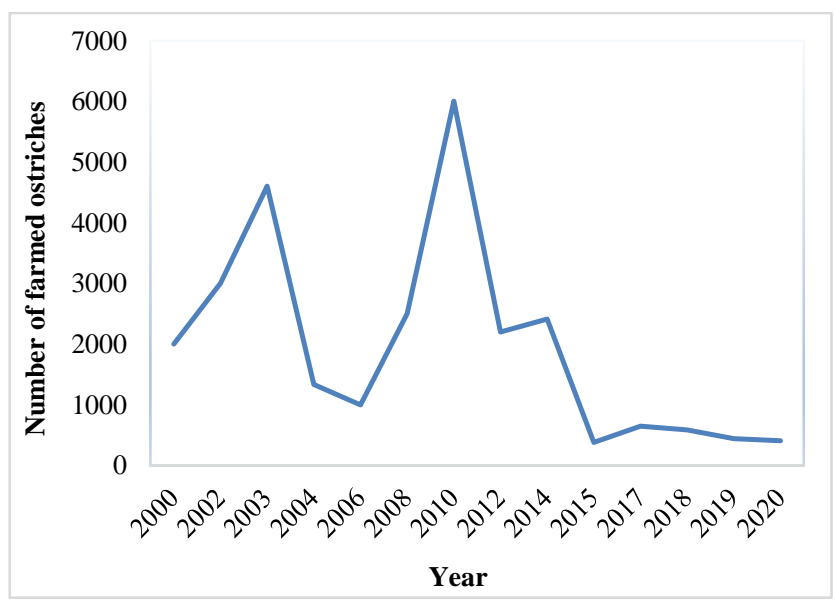

Figure 1. Number of farmed ostriches in Botswana from 2000 to 2020. Source: DAPR Reports (2017 to 2020), Statistics Botswana (2018), Mushi et al. (1999), The ComMark Trust/BIDPA (2005).

Many factors contributed to the poor performance of the ostrich industry, which has collapsed. These include high input costs especially feed expense, prolonged closure of the abattoir, lack of access to finance, inadequacy of extension service (Moreki and Kgakole, 
2015), high start-up costs, inadequate farmer training, limited infrastructure, unreliable feed supply, and unavailability of chicks (Anon, 2008). Similarly, Kistner (2019) reported that high feed costs and high investment and operating costs have a detrimental effect on the profit margins of ostrich enterprises in Australia, Botswana, Brazil, Israel, Namibia, Zimbabwe, etc. Lack of infrastructure was also found to be a challenge in the development and sale of value-added products in Mexico (Islas-Moreno and Rendón-Medel, 2019). Moreki and Seabo (2011) reported the three major challenges in commercial ostrich production in Botswana to be frequent closures of the abattoir, lack of access to credit, and inadequate extension support.

However, it appears that the frequent closures of the abattoir is the main contributor to the poor performance of the ostrich industry as it left farmers with no option but to depopulate their farms. Malope et al. (2015) attributed the decline in ostrich population to a lack of market outlets following the closure of the EU registered abattoir. This resulted in farmers reducing ostrich numbers on farms or stopping production, thus leading to a decline in the commercial ostrich population. Despite the health benefits associated with ostrich meat, the consumption of meat is low in Botswana, indicating that the local market is undeveloped. The low consumption of ostrich meat could be attributable to its high price due to its limited availability in the market and its high quality compared to other meats such as beef, chicken, and pork. Ostrich meat is expensive and is sold only in hotels in Botswana. In a related study, Buochuama (2018) in Nigeria advocated for the publicization of the health benefits of ostrich meat to attract more consumers and other players in the industry. A previous study by Dzoma and Motshegwa (2009) reported a lack of record-keeping as a challenge in commercial ostrich farming. Lack of record-keeping points to the inadequacy of technical support by the government extension services. Poor animal management reported by Masilo and Madibela (2003) also indicates the inadequacy of extension services. This makes the inadequacy of extension service to be one of the major challenges in ostrich production in consonance with Moreki and Seabo (2011).

Animal health challenges in neighboring countries also have a bearing on the development and performance of the ostrich industry with the major Transboundary diseases being Newcastle disease and avian influenza. The outbreak of H5N8 in South Africa, Namibia, and Zimbabwe in April-May 2021 as reported by FAO (2021a) resulted in a ban on imports and exports of poultry and poultry products. Prior to this, outbreaks of H5N1 and H5N8 were reported in poultry in South Africa during January-February 2021 (OIE, 2021). The World Organisation for Animal Health reported that a flock of exotic backyard poultry tested positive for the $\mathrm{H} 5 \mathrm{~N} 1$ virus in Kgatleng District of Botswana during the third week of July 2021, making it the first case in the country (FAO, 2021b). This resulted in the Ministry of Agricultural Development and Food Security banning the movement of live birds, eggs, meat, and feathers within and out of the Bokaa extension area (Kgatleng district) to contain the outbreak. The outbreak of avian influenza in neighboring countries results in the ban on imports, which has a bearing on the availability of ingredients required for the manufacture of ostrich feeds and the supply of veterinary requisites across the country, thus leading to the industry's poor performance. The closures of borders due to Newcastle disease and avian influenza also affect exports of ostrich products to international markets.

The decline in ostrich population from 2010 to 2013 was majorly ascribed to the prolonged closures of the abattoir, which gave rise to CEDA and other financial institutions not being willing to fund new ostrich projects as they were not financially viable due to lack of market access (Moreki and Kgakole, 2015). A previous study by BIDPA and The World Bank (2006) also reported that industry participants indicated that CEDA has not been forthcoming in funding ostrich projects.

\section{CONCLUSION}

The present review provides the history of ostrich farming in Botswana and the current status of the industry. To date, commercial ostrich farming does not exist in Botswana despite suitable climatic conditions and government support. The major challenges faced by the ostrich industry are frequent closures of the abattoir, lack of access to finance/credit, inadequacy of extension support, high feed expense, and unreliable feed supply. To revive the industry, active participation of the private sector is required. In addition, there is a need to develop a special support program that subsidizes feeds, birds, and shelters. It is important that the ostrich strategy that was developed in 2015 is implemented to guide the resuscitation process.

\section{DECLARATIONS}

\section{Authors' contributions}

John Cassius Moreki conceptualized this study, surveyed literature, drafted and revised the manuscript. 
Mogi Ivy Moseki was responsible for data acquisition and revision of the manuscript while Freddy Manyeula edited and suggested changes to the manuscript.

\section{Competing interests}

The authors declare that they do not have competing interests.

\section{Ethical considerations}

Ethical issues (including plagiarism, consent to publish, misconduct, data fabrication and/or falsification, double publication and/or submission, and redundancy) have been checked by the authors.

\section{REFERENCES}

Abdelkader HAR (2018). Ostrich, an analytical study in economic geography. International Journal of Academic Multidisciplinary Research, 2(12): 69-82. Available at: http://ijeais.org/wpcontent/uploads/2018/12/IJAMR181207.pdf

Al-Khalifa H, and Al-Neser A (2014). Ostrich meat: Production, quality parameters, and nutritional comparison to other types of meats. Journal of Applied Poultry Research, 23: 784-790. Available at: http://www.dx.doi.org/10.3382/japr.2014-00962

Anon (2008). Ostrich production struggling in Botswana. Poultry World. Available at: https://www.poultryworld.net/Other-PoultrySpecies/Ostrich/2008/4/Ostrich-production-struggling-inBotswana-WP002441W/

Barnes JI (1998). Wildlife economics: A study of direct use values in Botswana's wildlife sector. PhD Thesis. University College, London. United Kingdom. Available at: https://discovery.ucl.ac.uk/id/eprint/10106648/1/Wildlife_economic s_A_study_of.pdf

Botswana College of Agriculture (BCA) (2008). Botswana situational analysis on agricultural research and training: Final report. Available

at:

http://faraafrica.org/wpcontent/uploads/2015/04/LesothoSitAnalysis FinalReport-for-ICART-AnnorFrempong.pdf

Beyleveld AJ (1967). Ostrich farming in South Africa. Agrekon, 6(3): 14-16. DOI: http://www.doi.org/10.1030/03031853.1967.9525051

Botswana Institute for Development Policy Analysis (BIDPA) and The World Bank (2006). Prospects for export diversification in Botswana. Gaborone, Botswana. Available at: https://documents1.worldbank.org/curated/en/27982146819915127 0/pdf/696800ESW0P0990UBLIC00PROSPECTSBOOK.pdf

Botswana Government (1994). Ostrich management plan policy. Botswana Government Printer, Gaborone, Botswana.

Buochuama A (2018). Ostrich farming: A wildlife management option for restraining Nigeria's lingering farmers-herders conflicts. World News of Natural Sciences, 18(2): 232-240. Available at: https://agro.icm.edu.pl/agro/element/bwmeta1.element.agro100e8f21-764e-463e-a7b3-b0f20b2a0fa1

Chemis VJ (2009). Studies on the possible causes of losses in ostrich production and in selected farms in Kenya. Master of Science in Veterinary Pathology, Microbiology and Parasitology Thesis. University of Nairobi, Kenya. Available at: http://erepository.uonbi.ac.ke/handle/11295/19110

Cloete SWP (2014). Breeding ostriches. Ostrich Manual, pp. 24-39. Available https://www.elsenburg.com/sites/default/files/ebooks/2015-0429/Ostrich\%20Manual English\%20ed \%202014 content.pdf

Department of Agriculture, Forestry and Fisheries (DAFF) (2011). A profile of the South African ostrich market value chain. Available at: https://www.nda.agric.za/docs/AMCP/OstrichMVCP11-12.pdf

Department of Animal Production Reports (DAPR) (2017 to 2020). Ministry of Agricultural Development and Food Security. Gaborone, Botswana.

Department of Animal Production (DAP) (2021). Ministry of Agricultural Development and Food Security, Gaborone, Gaborone.

Dzoma BM, and Motshegwa K (2009). A retrospective study of egg production, fertility and hatchability of farmed ostriches in Botswana. International Journal of Poultry Science, 8(7): 660-664. DOI: https://www.dx.doi.org/10.3923/ijps.2009.660.664

Eltom SEM, and Al-sehemi A (2004). Chemical studies on ostrich oil obtained from (Struthio camellus). DOI: https://www.dx.doi.org/10.13140/RG.2.1.1693.0648

Food and Agriculture Organization of the United Nations (FAO) (2021a). Sub-Saharan Africa HPAI Situation update. Emergency Prevention System for Animal Health (EMPRESS-AH). Available at: https://www.humanitarianresponse.info/fr/operations/nigeria/docum ent/sub-saharan-africa-hpai-situation-update-fao-animal-health$\underline{\text { service }}$

Food and Agriculture Organization of the United Nations (FAO) (2021b). Sub-Saharan Africa HPAI situation update. Emergency Prevention System for Animal Health (EMPRESS-AH). Available at: https://www.fao.org/ag/againfo/programmes/en/empres/HPAI_Afri ca/situation update.html

Gaoswediwe N (2017). Ostrich farming lucrative business. Kutlwano Magazine, 55.

Hansard No. 2-00 (2020). Daily Hansard. The First Meeting of the Second Session of the Twelfth Parliament (Botswana), Tuesday $1^{\text {st }}$ December 2020. pp. 25-26. Available at: https://www.parliament.gov.bw/index.php/parliamentarybusiness/2012-12-13-13-08-42/hansard-english-version-2016

Islas-Moreno A, and Rendón-Medel R (2019). History and current situation of commercial ostrich farming in Mexico. Journal of World's Poultry Research, 9(4): 224-232. DOI: https://wwwx.doi.org/10.36380/jwpr.2019.28

Jeffrey JS (1993). Ostrich Production. Texas Agricultural Extension Service. Available at: https://hdl.handle.net/1969.1/160381

Kistner C (2019). Ostrich production today: The (eco)logical way to economic success. Lohmann Information, 53(1): 16-23. Available at: $\quad$ https://lohmann-breeders.com/media/2020/08/VOL53KISTNER-Ostrich-Production-.pdf

Magige F, and Røskraft E (2017). Medicinal and commercial uses of ostrich products in Tanzania. Journal of Ethnobiology and Ethnomedicine, 13: 48. DOI: https://www.doi.org/10.1186/s13002$\underline{017-0176-5}$

Malope P, Maripe O, and Ramokate B (2015). Trends in livestock production and productivity: What do the 2015 agricultural census results say? Botswana Agricultural Census, Analytical Papers, pp. 13-21. Available at: https://www.statsbots.org.bw/sites/default/files/Botswana\%20Agric ulture\%20Census\%20Report\%20Final\%202015._1.pdf

Masilo BS, and Madibela OR (2003). Report on the state of the world animal genetic resources (AnGR): Botswana Country Report. Botswana. Available at: https://www.fao.org/3/a1250e/annexes/CountryReports/Botswana.p df

Medina FX, and Aguilar A (2014). Ostrich meat: Nutritional, breeding, and consumption aspects. The case of Spain. Journal of Food and 
Nutrition Research, 2(6): 301- 305. DOI: https://www.doi.org/10.12691/jfnr-2-6-6

Moreki JC, Kebonye NM, and Tiroesele B (2012). Commercial ostrich farming in Botswana: A case study of dibete ostrich multiplication unit. Journal of Life Science and Biomedicine, 2(5): 192-195. Available at: http://jlsb.scienceline.com/attachments/article/17/J.\%20Life\%20Sci.\%20Biomed.\%2 02(5)\%20192-195,\%202012,\%20B37.pdf

Moreki JC, and Kgakole B (2015). Commercial development of the ostrich industry in Botswana. Journal of Agriculture Science and Technology, 11(8): 1963-1972. Available at: http://www.aatsea.org/images/conference publications/pdf/v11 n8 15 DecemberSpecialissue $/ 037 \% 20$ \%20John\%20Cassius\%20Mor\%C3\%AAki\%20-S3.pdf

Moreki JC, and Seabo D (2011). Critical review of the ostrich industry in Botswana. International Journal of Tropical Agriculture and Food Systems, 5(2): 125-129. Available at: https://www.ajol.info/index.php/ijotafs/article/view/86546

Msheila WP, Abdu PA, Abdussamad AM, Wakawa AM, and Malumfashi AI (2011). Ostrich management practices in three states of Northern Nigeria. Veterinary World, 4(2): 64-67. Available at: http://www.veterinaryworld.org/Vol.4/February\%20$\% 202011 /$ Ostrich\%20Management\%20practices\%20in\%20three\%2 0states\%20of\%20Northern\%20Nigeria.pdf

Mushi EZ, Isa JFW, Chabo RG, Modisa L, and Kono P (1999). Commercial ostrich farming in Botswana. South African Journal of Animal Science, 29(3): 262-266. Available at: https://agris.fao.org/agrissearch/search.do?recordID $=$ ZA2000000489

National Agriculrural Marketing Council (NAMC) (2010). The South African Ostrich Value Chain; Opportunities for Black Participation and Development of a Programme to Link Farmers to Markets. Available at: $\quad$ https://www.namc.co.za/wpcontent/uploads/2017/09/Ostrich-Value-Chain-Report.pdf
Sadeghnejad Z, Karampourian A, Borzou SR, Gholyaf M, Mohammadi Y, and Hadadi R (2021). The Effect of Ostrich Oil as a Complementary Medicine on the Severity of Pruritus and Quality of Life in Hemodialysis Patients. Complementary Medicine Research, 28: 40-45. DOI: https://www.doi.org/10.1159/000508288

Seleka TB (2005). Challenges for agricultural diversification in Botswana under the proposed SADC-EU Economic Partnership Agreement (EPA). SSRN Electronic Journal. DOI: https://www.doi.org/10.2139/ssrn.2686117

Shanawany MM (1995). Recent developments in ostrich farming. World Animal Review, 83 1995/2. Available at: https://www.fao.org/3/v6200t/v6200T02.htm

Snyders M (2020). Perceptions about commercial ostrich farming: Views of consumers, farmers and secondary stakeholders. Master of Agricultural Sciences (MSc Agric) in Animal Science Thesis. University of Stellenbosch, South Africa. Available at: https://scholar.sun.ac.za/handle/10019.1/109073

Statistics Botswana (2018). Botswana agricultural census report 2015. Gaborone, Botswana. Available at: https://www.statsbots.org.bw/sites/default/files/Botswana\%20Agric ulture\%20Census\%20Report\%20Final\%202015. 1.pdf

The ComMark Trust/ BIDPA (2005). The potential for export diversification in Botswana: Ostrich products case study. Available at: https://media.africaportal.org/documents/TheOstrichSector.pdf

Wessels PL (2003). An analysis of the potential for the marketing of ostrich meat in RSA. Master of Business Administration Thesis. Port Elizabeth Technikon, RSA. Available at: https://vital.seals.ac.za/vital/access/manager/PdfViewer/vital:10930 ISOURCEPDF?viewPdfInternal=1

World Organization for Animal Health (OIE) (2021). Highly Pathogenic Avian Influenza (HPAI) Report No. 21: January 15 to February 04. HPAI situation update. Available at: https://www.oie.int/app/uploads/2021/03/hpai---asof04022021.pdf 